\title{
Sustainable development of plant tissue culture industry: The Indian scenario
}

\author{
Shashank M. Patil ${ }^{1}$, V. B. Chandana Kumari ${ }^{1}$, K. Sumana ${ }^{3}$, S. Sujay ${ }^{1}$, M. Tejaswini ${ }^{1}$, Prithvi S. Shirahatti ${ }^{2}$, Ramith Ramu ${ }^{1 *}$ \\ ${ }^{1}$ Department of Biotechnology and Bioinformatics, School of Life Sciences, JSS Academy of Higher Education and Research, Shivarathreeshwara Nagar, Mysuru, \\ Karnataka, India, ${ }^{2}$ Department of Biotechnology, Teresian College, Siddhartha Nagara, Mysuru, Karnataka, India, ${ }^{3}$ Department of Microbiology, School of Life \\ Sciences, JSS Academy of Higher Education and Research, Shivarathreeshwara Nagar, Mysuru, Karnataka, India.
}

\begin{tabular}{|c|c|}
\hline ARTICLE INFO & ABSTRACT \\
\hline $\begin{array}{l}\text { Article history: } \\
\text { Received on: July 08, } 2020 \\
\text { Accepted on: August 09, } 2020 \\
\text { Available online: March 10, } 2021\end{array}$ & $\begin{array}{l}\text { During the last century, tremendous advancements have been achieved in the field of plant tissue culture (PTC) with } \\
\text { respect to adopting newer technologies, ideas, and their implementation. Since the beginning, artificial production } \\
\text { of plants was insisted by scientists, to minimalize dependence on natural resources. Increased demand for yield and } \\
\text { disease resistant plants stipulated the large-scale production of plants, which brought large-scale production to light, }\end{array}$ \\
\hline $\begin{array}{l}\text { Key words: } \\
\text { Plant tissue culture, } \\
\text { Commercialization, } \\
\text { Micropropagation, } \\
\text { In situ conservation, } \\
\text { Germplasm conservation, } \\
\text { Pilot studies, } \\
\text { Protocol refinement }\end{array}$ & $\begin{array}{l}\text { as a new source producing thousands of plants using an explant. As a result of globalization, countries around the } \\
\text { world have initiated commercialization of PTC and this became a global phenomenon, due to the huge turnover and } \\
\text { demand from developing countries. Through the modification of micropropagation techniques, Indian PTC industry } \\
\text { has been successful in sectors such as agriculture, medicine, and forestry. Measures such as in situ conservation, } \\
\text { germplasm conservation and exchange, pilot studies, and their protocol refinement have revolutionized the Indian } \\
\text { PTC industry. This review deliberates on the PTC commercialization in India and contemporary world, research and } \\
\text { development status, and constraints associated with PTC industry. Thus, we have reviewed the problems associated } \\
\text { with Indian PTC industry and suggest few aspects that may help in the restoration of the same. In this review, } \\
\text { using keyword searches over } 465 \text { results appeared, of which } 60 \text { studies were considered relevant and thus carefully } \\
\text { reviewed in the present article. }\end{array}$ \\
\hline
\end{tabular}

\section{INTRODUCTION}

Plants are considered as a sacred gift of nature to the humankind. It is attributed to their nature of productivity and role playing in maintenance of a healthy environment. Plants have been used for the benefits of human beings in various aspects. For example, man has been growing plants that are used for food, feed, fiber, oil, ornamental, and industrial purposes since time immemorial. Apart from crops, these are also used for oxygen, wood, leaves, fruits, and metabolites produced [1]. Some of these plant products do possess medicinal values, which help in the prevention of medical abnormalities [2]. Hence, they play an important role in maintaining a balanced food chain [3]. Unlike microorganisms and animals, plants cannot move. Thus, it becomes essential for them to get nutrients and growth factors at the site of their growth. The sedentary nature of plants can affect their growth and multiplication in various ways. The availability of nutrients in soil, supporting physical parameters such as temperature,

*Corresponding Author

Ramith Ramu,

Department of Biotechnology and Bioinformatics,

School of Life Sciences, JSS Academy of Higher Education and Research,

Shivarathreeshwara Nagar, Mysuru - 570015, Karnataka, India.

E-mail: ramith.gowda@gmail.com humidity, $\mathrm{pH}$ of soil, salinity, water level, and moisture can affect the growth in both supporting and refuting ways [4,5]. Apart from these factors, abnormalities such as diseases, overgrazing by cattle, slash-and-burn of agriculture by humans, forest fires, volcanoes, and insect pests can significantly reduce the number of plants within a region. This may result in either temporary or permanent (in the case of endangered species) loss of crop/plant that can lead to further environment related complications [6,7]. Ancestors used to resolve this problem by preserving seeds with desired qualities. These seeds known as "landraces" were preserved for longer durations and were sown to restore the crop health. Landraces were the wild varieties retaining old set of conserved genes from the ancestral species. The propagation of these units was performed to grow a greater number of plants with same traits [8].

The problem of reduction in the number of plants can be effectively resolved with plant tissue culture (PTC). Various techniques followed in this method of artificial generation of new plants can be used to new and healthy plants with similar characters of the parent plant. This method of generating new plants in artificial conditions is known as "in vitro" approach. The in vitro approach is associated with aseptic culturing of cells, tissues, organs, or whole plant under artificial conditions with reference to nutrition and environment [9-11]. PTC is aimed to produce clones of plants. For the generation of clones, it 
is essential to facilitate the culture with a suitable environment for the optimum growth and multiplication. These factors create an artificial microenvironment, in which plants grow and multiply. As a result, the generated clones possess true-to-type of selected genotype. Thus, PTC technology is being widely used for large scale multiplication and industry. Apart from research view, techniques of PTC prove to have significant industry potential in the areas of micropropagation, plant quality improvement, secondary metabolite production, disease resistant plant production, and others [12,13]. Small pieces of the tissue (explants) are used to produce thousands of new plants with the help of PTC. This process is completed within a short period of time and space under controlled conditions, irrespective of weather and flowering/pollination season. With the help of PTC, endangered and threatened species can be successfully grown and conserved [14]. This is aided by high degree of multiplication and minimal requirements of sources. In addition to this, PTC is recognized as a most efficient technology for crop improvement by the production of gametoclonal and somaclonal variants. In addition to this, due to the possible occurrence of somaclonal variability, certain callus cultures were able to inherit characters from parent plants. This helps in the commercial production of plants [15]. Production of plants at commercial scale using micropropagation techniques proves to be beneficial over traditional methods such as cutting, grafting, seed, and air-layering. Along with the disease resistant plants, high yields and nutrient rich plants can also be produced with the help of PTC [10,11].

From time immemorial, India has been a rich source of medicinal plants. The richness is attributed to the supporting climate and physical parameters that created natural hubs such as Western and Eastern Ghats with north-eastern hills [16]. With the help of PTC, these species can be identified, screened, and can be cultured with in vitro approach. This helps in regeneration of medicinal plants and may also help in large scale production if required by pharmaceutical industries [17]. The current review was carefully planned considering the lack of literature on the various aspects of PTC industry in India. PubMed and Google search engines were employed to search for the relevant manuscripts related to the recent advances in PTC to identify over 1000 manuscripts resulting from the keyword search. After elimination of duplicates and non-relevant contents, around 60 manuscripts were used to review the findings and to write this article. This review focuses on the emergence of PTC in India and rest of the world along with the followed methods. It depicts the events associated with R\&D activities in India, institutions funding the research, private organizations involved with PTC and commercial production of crop plants, medicinal plants, and forest trees. It also deliberates the constraints and remedies need for restoration.

\section{HISTORY}

The history of PTC dates to early $20^{\text {th }}$ century when Gottlieb Haberlandt, in 1902 addressed the German Academy of Science on his experiments on in vitro single cell culture. Later, his idea of generating the whole plant from a part, now known as "totipotency" got established, which also gave rise to the artificial growing of isolated plant cells using nutrient solution. This approach resulted in the successful culture of root and stem tips using meristematic cells which were completed later using a completely defined medium by Kolte and Robbins in 1922. With the first plant hormone (indole acetic acid) discovered by Went in 1926 and Vitamin B included as an ingredient in media by White in 1934, embryo culture was successfully developed. Later, embryo rescue from non-viable seeds was also performed. In 1939, Gautheret developed the first callus culture along with White and Nobecourt. Overbeek added the coconut milk and reported the cell division in Datura during 1941.
In the context, "nurse culture" was developed with using filter paper as a substrate for plant growth. Whole plant regeneration using shoot tip culture was reported by Ball in 1946 using Lupinus plant. As the principle of PTC was then shifted toward enhancing the plant growth, research was focused to improve the nutrient media with the addition of plant hormones. Miller and Skoog discovered kinetin hormone and reported its use in cell division in 1955. The same duo also gave the concept of hormonal control in the plant organ formation $[9,18]$.

In a similar attempt like Ball from 1946, Reinert and Steward developed bipolar somatic embryo from carrot independently along with unipolar shoot buds and roots in 1959. The conventional method of using coconut water was soon replaced by defined medium, when Murashige and Skoog developed it using micro and macro elements, vitamins, growth regulators, and carbon source in 1962. Before that in 1960 , Cocking was able to isolate protoplast by cell wall degradation by enzymatic method. Later in the same year, Kanta and Maheshwari developed test tube fertilization. Using anther culture, Maheshwari and Guha produced first haploid plants of Datura in 1964. Regeneration attempt with carrot plants from single cells of tomato was also successful in 1966. After the isolation of protoplasts by Cocking, Power et al. achieved the protoplast fusion 1970, whereas Takebe et al. developed the first plants from these protoplasts in 1971. As a result, pomato was produced by hybridizing tomato and potato by Melchers in 1978. The recent past which includes 1980s witnessed a dramatic increase in the applications that resolved several problems related with basic biology, forestry, agriculture, and horticulture. Agrobacterium tumefaciens was used to integrate its Ti plasmid in plants by Chilton in 1977. The biotransformation was ubiquitously to generate pathogen resistant plants in following days. Meanwhile, techniques such as cryopreservation and germplasm preservation were also developed. As a result of this, more plants produced, in turn, will help to get more plant products that include secondary metabolites, herbal extracts, and oils. The first attempt in 1950s made by Charles Pfizer Co. US was then extended with Germany and Japan executing feasible industrial application of cell cultures in 1978. The modern wave includes development of shuttle vectors, selectable markers, and direct DNA transferring techniques for incompatible plants. This has resulted in considerable success controlling insect pests, weeds, and diseases. On the other hand, plant quality has been improved by gene transfer techniques, developing biofortified species such as Golden Rice. The next wave of PTC is in progress with applications including agricultural biotechnology, pharmaceuticals, and environmental aspects. Indeed, advancements made with in vitro technology in the last century have gone well beyond the imagination of Haberlandt $[9,18]$.

\section{COMMERCIALIZATION: A SCENARIO OF INDIA AND CONTEMPORARY WORLD}

The extent of globalization created a surge in requirement of food products as well as medicines. Increased production of medicines also resulted in expansion of pharmaceutical industry, thereby increasing the requirement for raw materials such as plant extracts and chemical compounds $[19,20]$. Although modern-day PTC involved with the micropropagation, it is limited to lab scale production which greatly differs from commercial or large-scale production. Thus, it becomes important to establish PTC industries well-equipped with all the facilities that permit extensive production of plants to produce plant products required by the pharmaceutical industry.

Due to the above factors, commercial application of PTC was first established in US with micropropagation of orchids in 1970s. Since 
then, the industry has witnessed tremendous support and global expansion. The number of production units as well as number of plants has been increased from 1985 to the present [21]. The current scenario depicts the presence of enough scope for the expansion of commercial PTC as the demand far exceeds production, with an estimated 15 billion USD market per annum. The global biotechnology business is estimated to be approximately 150 billion USD, of which $50-60 \%$ is attributed to agri-business which raises annual demand of tissue culture products by $10 \%$. During 1990, production increased from 130 to 500 million plants, where five major commercial units produce 15-20 million plants per annum. Although it appears like PTC industry is nearly halted in developed countries due to increased production charges, in case of developed countries like India, the production is quite stable because of the lower wage scales. This leads to the production of plants at cheaper costs. The Western Europe has a capacity to produce 212 million plants, with 37 units producing more than 1 million plants per annum. Netherlands produces about 62 million reengineered plants every year with 67 commercial units. In Germany, the production raises up to 8 million with 21 functional units [22].

The first commercial tissue culture in India was established in 1987. It was named as A.V Thomas Company, Kerala. Cardamom plants containing superior genotypes of selected variety were clonally propagated by them to bring out the plant improvement. The production of these plants was done in small scaled laboratory-based industry, which was developed indigenously and released by the National Chemical Laboratory (NCL), Pune, India. This technology was refined to make the methods oriented toward more production, economically feasible, and quality service with the help of a UK based firm [23]. In 1988, the second plant was started, an Indo-American Hybrid Seeds at Bengaluru, Karnataka. They were reported with the hybrid flowers and vegetables nursery with imported PTC laboratory and green houses. By 1988, 4 units were working in India, and it was flowed by a rapid rise till 1996 to around 50 laboratories across the country. Even though the number rose to 105 , due to lack of financial support it was reduced to 70-75. With this, Indian micropropagation industry has raised from 5 million to 190 million in course of 8 years from 1988 to 1996 . The current scenario of Indian subcontinent shows that the facilities created have made our units competitive to those from leading countries such as US and Netherlands. Indian units need to work on generating unique products based on demand in both domestic and international markets to remain in profitable side and to earn essential foreign exchange [22].

\section{INDIAN MICROPROPAGATION UNITS INVOLVED IN COMMERCIAL PTC}

\subsection{Aims, Objectives, and Employed Techniques}

The commercial production of plants needs rapid propagation of superior varieties with increased yield. Although the rate of propagation varies in different species based on their genetic composition and environmental conditions, herbaceous species are preferred over woody perennials fort the enhanced production. Furthermore, herbaceous plants can be used for germplasm storage and can help in the maintenance of stock under controlled conditions [24]. Meanwhile, it becomes essential to eliminate plant propagative material to recover good yield at the end. Thus, protective measures like virus indexing can be performed with the explant before the culturing. It makes the progeny virus-free; hence, a better yield can be obtained [25]. In course of plant production, one must adhere to the maintenance of desirable genes in the produced plants. Regeneration from cell and callus suspension is more difficult than micropropagation. More research needs to be done in this aspect to develop genetically similar plants (somaclones) without the occurrence of any undesirable gene. With the advancements in plant biotechnology, it is possible to induce genes within the plant genome [26]. This can be exploited to induce desirable and heritable genes in regenerated plants. Along with this, techniques such as protoplast fusion and generation of plants from fused protoplasts also prove to be efficient for exchanging genetic material [27]. However, the selection of plants with superior genes, isolation, and inducing them in genetically diverse species is tedious and gruesome task [28,29]. In addition to these, embryo rescue also plays an important role. In PTC, embryos could use a hand in micropropagation, in case of failed cultures. Therefore, embryo rescue needs to be practiced with suitable modifications to endeavor a good yield of healthy plants [30-32]. From the repeated self-crossing pure breeding lines can be obtained, which can be further utilized for hybrid production and genetic studies. This enhances the efficiency of in vitro selection. The aims and objectives of PTC must be oriented toward the generation of healthy and multiple plants. In a world of demanding market for secondary metabolites and other plant products, commercial units must adhere to supply the required materials.

\subsection{Units Operating Across India}

Apart from central research laboratories, research centers, and universities, there are some PTC units involved in commercial micropropagation. Some of these laboratories work on regular basis, while some of them depend on the government. Financial and technological help is been given to them from the government to promote tissue culture industry in the country. Table 1 lists out the commercial PTC units located in India, along with their location and number of units. Most of them are in Maharashtra and Karnataka states. It is interesting to note that being a country of variety of climatic differences; India possesses these units across its land. For example, Rajasthan and Darjeeling have their units fully operative, despite extreme climate limitations in both the regions. They also vary in their management and production. Maximum yield is obtained by Kalindi Biotech, located in Rishikesh, Uttar Pradesh (20 million plants per year). The lowest amount of plants is produced in Costford Promoted Unit, Thiruvananthapuram, Kerala and Rallis India Ltd, Bengaluru, Karnataka, with only 0.1 million plants per year. Most of them lie in the range between 5 and 10 million plants per year. Considering the production and number of units present, Maharashtra tops the list of annual production with 31 million plants per year with 25 units. Karnataka stands second in line with 31 million plants with 9 units. Odisha and Rajasthan are reported to produce the lowest amount of plants 1 million per year with 1 units each. Table 2 depicts the annual outcome of states in India [23].

\subsection{Sectors Benefitted with Commercialization of PTC}

\subsubsection{Agriculture}

Agriculture sector is one the most benefitted sector due to the commercialization of PTC. Several crop plants and fruits have been propagated and resulted in the exponential rate of production. The major consumers of tissue culture plants are reported to be State Agricultural Departments, Horticulture Departments, Agri Export Zones (AEZs), paper manufacturing industries, sugar industries, private farmers, and floriculturists [33]. Major food crops such as wheat, rice, and ragi have been given preference with respect to the mass production and food security. Wheat crops have been generated from immature embryos and leaf segments on inducing additional plant hormones. Various protocols have been developed and refined to produce rice, even 
Table 1: Organizations involved in commercial micropropagation

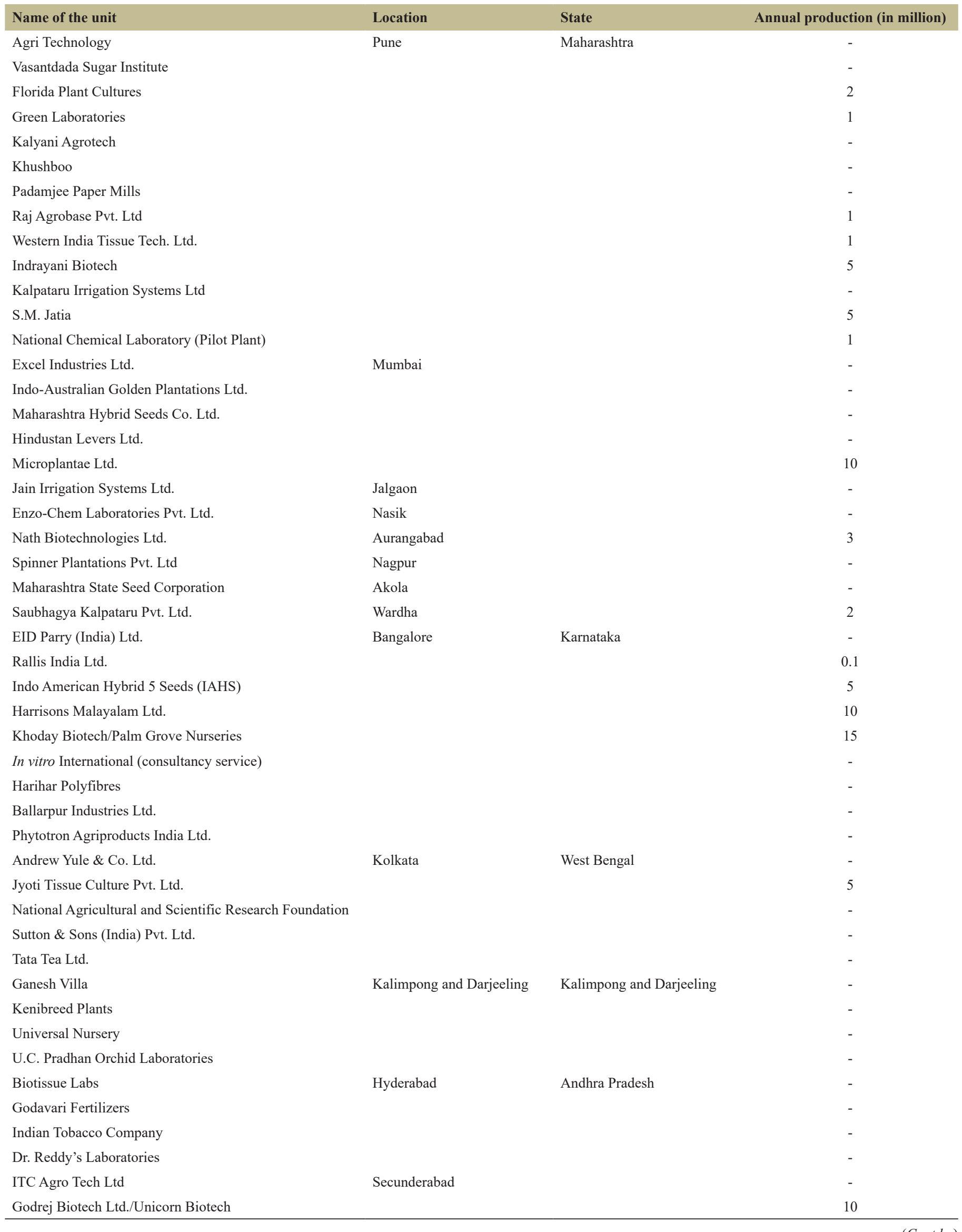


Table 1: (Continued)

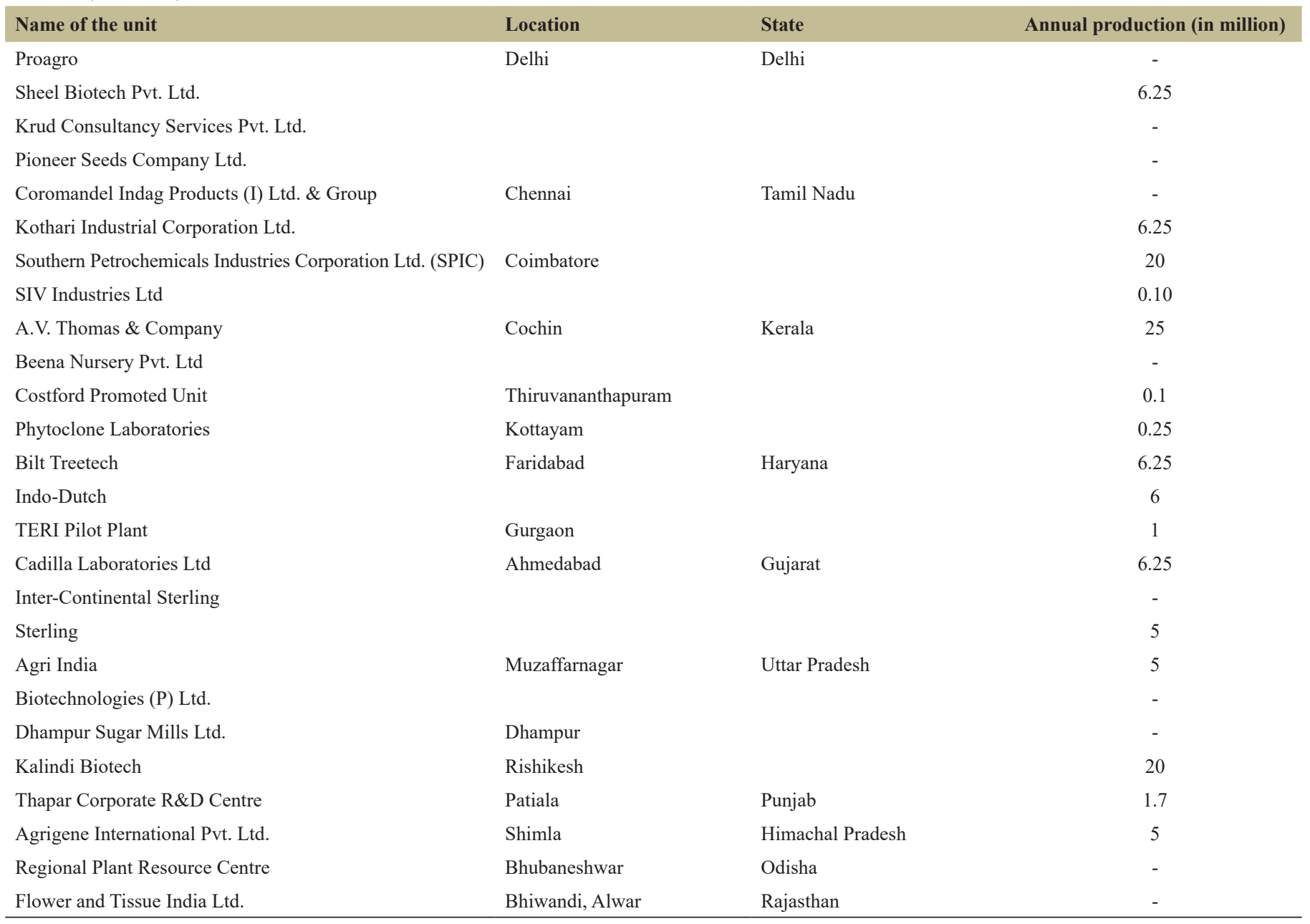

Table 2: Annual outcome of states with PTC units in India [23]

\begin{tabular}{lcc} 
States & Number of units & $\begin{array}{c}\text { Capacity of annual } \\
\text { production (in millions) }\end{array}$ \\
Maharashtra & 25 & 31.0 \\
Karnataka & 9 & 31.0 \\
West Bengal & 9 & 5.0 \\
Kalimpong (Darjeeling) & 4 & 1.0 \\
Andhra Pradesh & 6 & 10.0 \\
Delhi & 4 & 7.0 \\
Tamil Nadu & 4 & 27.0 \\
Kerala & 4 & 25.0 \\
Haryana & 3 & 13.0 \\
Gujarat & 3 & 12.0 \\
Uttar Pradesh & 3 & 25.0 \\
Punjab & 1 & 2.0 \\
Himachal Pradesh & 1 & 5.0 \\
Odisha & 1 & 1.0 \\
Rajasthan & 1 & 1.0 \\
\hline
\end{tabular}

from callus and immature embryos to improve production to meet up the expectations at global market. Finger millet or ragi has been a rich food of various nutrients. As the plant received minor attention compared to other crops such as maize, oats, and barley, development of protocols to improvise the production has been initiated [34]. Crops such as banana, sugarcane, mango, grapes, and other herbs are in great demand and therefore production using tissue culture methods can cater to these needs. By observing the rate of banana consumption, it will remain the most reliable source of income and a continuous market. Several laboratories found the higher amount of yields in tissue culture of banana. In Maharashtra, 52,000 Ha. land is under cultivation and $50 \%$ of this plantation has been completed using tissue cultured plants, with the production of 125 million plants annually [35,36]. In case of sugarcane, though it has been a popular crop in domestic market, rapid multiplication of new and efficient varieties is required. With the studies reporting increase in yields from tissue cultured varieties, sugarcane production can be efficiently reach new heights. Research institutes in Uttar Pradesh, Tamil Nadu, Maharashtra, and others carrying out experiments to increase the production of sugarcane [37]. In addition, being one of the largest exporters of mango fruits to the world market, India presently accounts for $39 \%$ of production. Over 1 million Ha. land used for mango cultivation, still there is a need to look after the poor quality of mangoes produced at R \& D level. In case of grapes, Indian Agricultural Research Institute (IARI) has released new varieties for production of wine, juice, raisin making, and table purposes. Even though "Arka neelamani" a black seedless hybrid, released from Indian Institute of Horticulture Research, Bengaluru has a great market potential, several other varieties need 
to be launched with higher market values [35]. Furthermore, with the help of PTC, herb export has been boosted three times within last few years. PTC has been helping to conserve the endangered species of plants. However, smarter techniques need to be found to enhance the production and marketing. For example, Trichopus zeylanicus has recently been in the mountainous pockets of Kerala. It is believed to be a vitality and energy enhancer. However, it is difficult to propagate and has a potential to expand its cultivation $[23,35]$.

\subsubsection{Medicine}

India comprises a great wealth of medicinal plants which have been used by tribals and locals since time immemorial. All the three levels of biodiversity, that is, genetic diversity, species diversity, and habitat diversity of medicinal plants are reported to be in greater numbers compared to other countries of the world. With the worldwide demand of 14 billion dollars, medicinal plant related trade in India estimates up to 1 billion per year. A total of 560 species of India are added under the Red List of threatened species, where 247 of them are in threatened category by International Union for Conservation of Nature and Natural Resources (IUCN) [38]. In the context, commercialization of PTC can be exploited to protect the medicinal plants in two possible ways, including (i) mass production of medicinal plants and (ii) conservation of rare and endangered species. The pharmaceutical industry aims to produce wide variety of secondary metabolites including alkaloids, tannins, steroids, quinones, terpenoids, and phenylpropanoids. Micropropagation of medicinal plants involves the same procedure as other plants [39]. Properties such as seed production, protection of elite plants from mutation, and production of plantlets in artificial conditions are given preferences. Furthermore, production of plants despite the presence of seasonal constraints using green house is done. The plants thus tend to develop in vitro targeted to be free of pathogens, especially viruses. The plants produced using vegetative propagation tends to show slow growth, thus they are supplemented with growth enhancers. Mass production of ornamental plants and mass cloning of pollinated and seed propagated trees is also targeted. Multiplication of sterile lines and germplasm exchange between national and international bodies is done to preserve endangered species. Furthermore, rare and unpopular species such as Geranium, Mentha, Paulownia, Aloe vera, and Banana have been marketed at international level [40]. In addition, species such as Chlorophytum borivilianum (Liliaceae), Datura metel (Solanaceae), Bacopa monnieri (Scrophulariaceae), and Catharanthus roseus (Apocynaceae) have been developed with refined protocols [41]. Furthermore, unpopular plants such as Aegle marmelos, Celastrus paniculatus, Commiphora mukul, Acorus calamus, Simmondsia chinensis, Peganum harmala, Prosopis cineraria, Sapindus mukorossi, Spilanthes acmella, and Stevia rebaudiana have been given importance with respect to mass production [39]. The Western Ghats of India have been one of the rich sources of medicinal plants. Government of India initiated the conservation genes of such plants in four gene banks. Special attention has been given to the plants of Western Ghats with respect to PTC protocol refinement and secondary metabolite production [42].

\subsubsection{Forestry}

Micropropagation in case forestry is highly focused on conservation of plant species as well as germplasm compared to medicinal plants. It is because yield of plant-based products is expected to be more in case of herbaceous species. The institutions and commercial units in India have been employed chiefly on refinement of protocols and extensive field trials to ensure the mass production of healthy plants [43]. Demonstration plantations have been set up to evaluate the economic impact to help the farmers and forest community. Furthermore, transferring of technology, exchange of germplasm at national and international levels, and generating awareness among the workers and the needy have also been practiced. Pilot studies appointed by Government of India have been conducted and reported the status of PTC in forestry. Using bamboo (Dendrocalamus strictus L.) plant, the optimal conditions for the collection of explants and their culturing methods were performed. The tests were successful as the micropropagated plants showed clonal homogeneity and better survival rate over seed raised progeny. The plants were also better in terms of measurements and growth in varieties of soil compared to the seed raised progeny. The genetic homogeneity was never found to be altered and was confirmed with DNA using Randomly Amplification of Polymorphic DNA (RAPD) technique. Later, demonstration at farmers land was also successful, with $38.91 \%$ more wood and a higher net profit of $42.0 \%$. Similar results were obtained for Salvadora persica, Tamarindus indica, and Eucalyptus spp. [43,44]. In addition to plant growth, much of the attention has been given to plant conservation. Based on the plant and climatic conditions, choice between in situ and ex situ conservation methods is made. Usually, endangered and nearly extinct species are chosen to be furthered with ex situ methods to avoid risks [45]. However, ex situ conservation requires more labor and cost management than the other. The collection of seeds, pollen, DNA, and field gene banks, botanical gardens are involved in ex situ approach. The in situ conservation is usually done in fields and greenhouses [46]. Apart from conservation, preservation also plays a significant role. Methods such as slow growth and cryopreservation are followed based on the type of plant preferred. Slow growth method is followed in case of short-term storage and vice versa. Molecular methods such as Restriction Fragment Length Polymorphism (RFLP), RAPD, and Polymerase Chain Reaction (PCR) are used to determine the genetic diversity. With the global climatic changes changing constantly, it becomes essential to save the susceptible plant species [47].

\section{STATUS OF RESEARCH AND DEVELOPMENT IN INDIA}

\subsection{Production Management}

Even though the idea of commercializing PTC started a decade later (1987), compared to the western counterparts, India now possess 73 commercial PTC units, majority of them located in Maharashtra (25) and Karnataka (9) [22]. In addition to this, PTC can also be practiced for research purposes in centralized institutions such as Indian Council of Agriculture Research, Delhi and National Chemical Laboratory, Pune. Despite the support of these research institutions, agricultural universities, and National Certification System for Tissue Culture Raised Plants (NCS-TCP) also extend the support for commercial production [48]. The size and production of these laboratories vary from one region to another. Their production capacity exists between 0.1 million and 20 million plants per annum. These laboratories have been categorized depending on their production area as well as capacity as small, medium, and large laboratories. The smaller laboratories with $<1.0$ million plants produced are about $70 \%$ of the total laboratories in number. About $20 \%$ of laboratories belong to medium scale that produces 1-10 million plants. Only few laboratories are working to produce 10-20 million plants per year. Including all these contributions, India is not able to cross 50 million benchmarks $[22,23]$. Due to this, it becomes evident that the appropriate utilization of laboratories is not done.

\subsection{Assistance to Commercialization of PTC}

The research and development activities are run by an array of institutions and research centers in India. For the smooth run of these units, some assistance is essential. The need of assistance is much 
appreciated both in terms of technology and economics. It is because India had only 4 operating units in 1980s, while rest of the world produced millions of plants. Even though number of units increased, the output was so minimal to reach up the quantity needed by agricultural and horticulture market needed [22]. Newer technologies, instruments and trained staff are required to run a commercial PTC hub. In addition to this, financial support is also an essential thing, as the handling of instruments and chemicals is expensive. There are number of schemes launched by Government of India and other states to promote the commercial production of PTC.

\subsubsection{Ministry of agriculture}

Financial assistance up to Rs. 21 lakhs for public sector and Rs. 10 lakhs for private sector commercial units is provided by the Department of Agriculture and Cooperation under the Ministry of Agriculture, Government of India, with a maximum of $20 \%$ of the project cost. A subsidy of $50 \%$ is provided by various state Governments under development of fruits scheme for purchasing banana plants grown with tissue culture. A national facility for quality control and diagnosing virus has been set up by Government of India in Delhi, which operates with the help of five satellite centers responds to the needs of tissue culture industries in various parts of the country. In addition, under Small Farmers Agri-business Consortium (SFAC), Ministry of Agriculture provides loans up to Rs. 50 lakhs for small scale PTC laboratories run by farmers through cooperative societies [33].

\subsubsection{Agriculture and processed food products export development authority (APEDA)}

A trans-shipment facility has been established by Government of India under the Ministry of Commerce and Industry at Bengaluru, Mumbai, and New Delhi airports. This facility provides up to $25 \%$ of airfreight subsidy in costs to supply tissue culture plants. A subsidy of $50 \%$ is given for the development of export promotion, market development, human resource development, feasibility studies, and organization building. It also includes the new infrastructure developments such as refrigerated van and innovative ideas in packing. In addition, financial support is also given for setting up quality control measures and their implementation of ISO 9000 [33].

\subsubsection{Department of biotechnology (DBT)}

DBT is the principal supporter of research and development projects in India. It functions alongside various universities, laboratories, and research academies for the development and refinement of PTC research. It has established six national centers for the detection and diagnosis of virus and control quality maintenance, which, in turn, deliver the virus-free plants. For the promotion of industrial PTC research, the department has set up micropropagation technology parks (MTPs) [33]. At present, there are two of the parks in National Chemical laboratory, Pune, Maharashtra and Tata Energy Research Institute, New Delhi. These parks are established in order facilitate a solid pavement for transferring novel research techniques to the needy entrepreneurs, working with large scale or commercial PTC. They also aid as a bridge connecting research centers and commercial tissue culture industries to enhance the commercialization of PTC [49]. The services offered by MTPs are given in Figure 1.

\subsubsection{National horticulture board (NHB)}

NHB, Ministry of Agriculture, Government of India, was established in 1984 for integrated development of horticulture. This board promotes the healthy development of horticulture industry. A back-ended capital subsidy below $20 \%$ of the total cost and up to Rs. 25 lakhs of cost are funded by NHB. It is even extended to the construction of greenhouses [33]. This scheme is greatly helpful to the economically backward farmers and villagers who cannot afford the instrumentation required for the construction of greenhouse.

\subsubsection{Financial institutions}

Apart from this, financial support is extended by different banks run by Government of India. This will help to establish new culture plants and renewing of the old ones. Centralized banks include State Bank of India, Dena Bank, Bank of Baroda, Central Bank of India, National Bank for Agricultural, and Rural Development (NABARD). Every institution differs from each other in terms of official essentialities [50].

\subsubsection{Biotech consortium limited}

Under the Indian Companies Act 1956, the Indian government established Biotech Consortium India Limited, supported by Department of Biotechnology, Government of India. This consortium has been involved with the development of technology, syndication of funds, project consultancy, dissemination of information, and training manpower. At present, it has assisted over thousands of clients comprising researchers, research institutes, entrepreneurs, corporate sector, banks, government, and public [50].

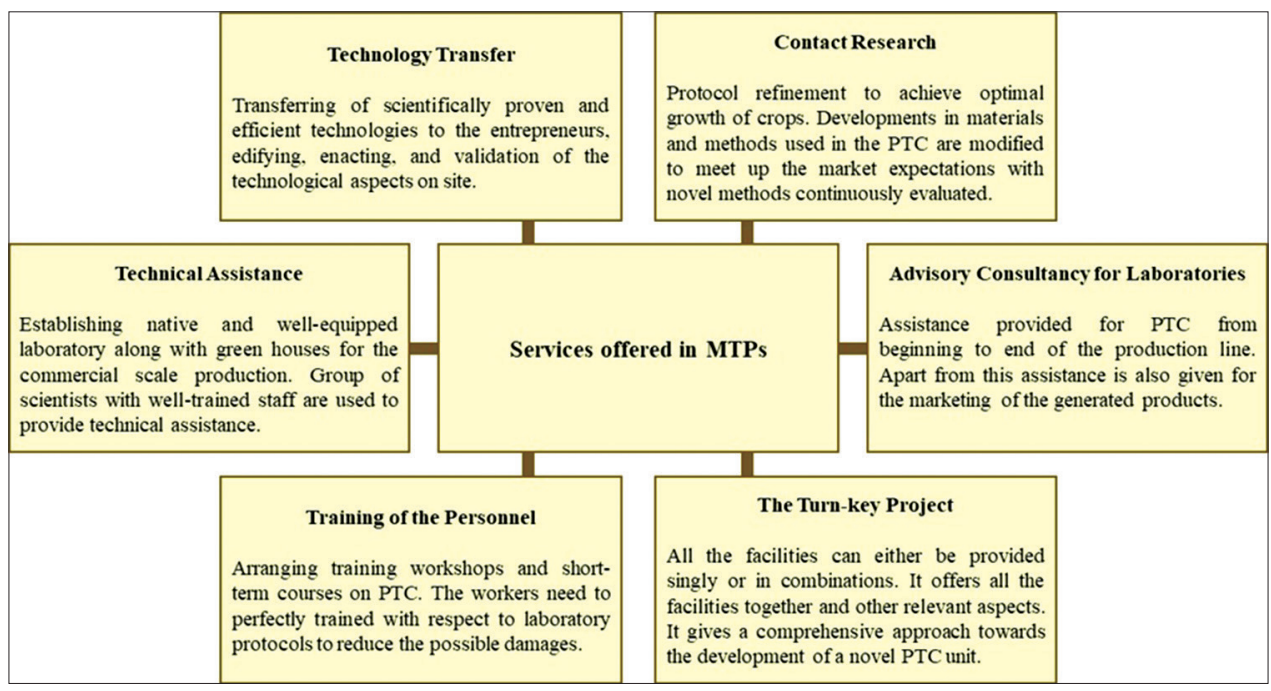

Figure 1: Services offered in micropropagation technology parks 


\subsubsection{State level initiatives}

Indian states including Andhra Pradesh, Gujarat, Maharashtra, and Karnataka facilitate financial assistance under agro-industrial scheme, for establishing PTC units. Among these, Government of Karnataka gives a capital subsidy of $20 \%$ on all PTC investments [33].

All the above stated facilities have been encouraging the establishment, production, and marketing of tissue culture products in the micropropagation industries. This has enormously helped the farmers and the industrialists to procure the financial as well as technical assistance. This comprehensive approach by the Government and the industries could endeavor to reveal the true potential of Indian PTC industry, which can become a landmark global market in $21^{\text {st }}$ century.

\section{PERSPECTIVES AND PROJECTIONS}

The commercial approach to the conventional PTC has resulted in harboring a wide range of techniques that have revolutionized the production thereafter. Since the beginning, all the steps followed in the PTC have been continuously refined by the researchers in search of resultant plants with high yield, resistance to pathogens and environmental aberrations. Although affected by lag of 10 years, the Indian PTC industry has been evolved to equal with its Western counterparts [33.36]. The production of tissue cultured plants has been increased dramatically since the extension of support from the Indian Government in terms of finance and technology. Several applications in agriculture, medicine and forestry have been projected by the PTC. For example, with the advancements in genetic engineering, nutrient enriched crops such as "Golden Rice" have been grown [51]. However, there is an utter requirement of drought resistant crops that may grow with minimal requirement of water. As the Indian climate proves to be harsh for many of the crops especially during summer, drought hit regions could use the benefits from PTC, in terms better varieties of crop plants. Even with the sublime research on major Indian fruits such as banana [52], guava [53], and mango [54], their pharmaceutical importance is not utilized to produce plant-based drugs. The production of plant-based drugs and their marketing at international level needs attention. Apart from crop plants, India is referred as a cradle of medicinal plants. Although many of the agencies have promoted the benefits of these plants in the international market, there is a sublime dependence on synthetic drugs, even with their known side effects [55]. Therefore, attention is needed on the production and marketing of such plants.

It is applaudable that the government has been doing its best in terms of providing technical and financial assistance. But practicing of PTC in villages and remote areas has not been took off as it was expected. Farmers in village need to be edified about the benefits of PTC through demonstrations by group of scientists and industrialists. Soil health cards and subsequent suggestions to enhance their fruit and crop production through PTC can be distributed to the farmers. Furthermore, the quantification and quality of micropropagation in plants are still been a difficult task. Structural features such as number of leaves, stem calipers, number of shoots at clump, number of roots per plant, and weight and diameter of bulbs have not yet used to define the quality of the plants obtained [56]. Costing of the plants is not yet taken as a serious concern for the competitive production of plants at global level. Professional credibility has not been established by gaining a recognized position in the market. Poor marketing skills and resistance to foreign product sales are not observed [36].

Furthermore, it is known that Indian research institutes have been exchanging the germplasm at national and international levels [57]. In the context, inducing genes that result in good yield and resistance to diseases could help in the robust development of industry. Furthermore, genome sequencing could reveal both harmful and beneficial effects of mutations, which can be dealt for the modification of plant species. Plant proteins have been the center of interest as they possess substantial amount of nutraceutical values. Bioactive peptides from medicinal plants would sure be able to comprise medicinal benefits [58]. Thus, PTC industries need to focus on these aspects alongside secondary metabolites. In total, the PTC industries could be more worthy if they deliberate on parallel ways of scientific research and commercialization at international level.

\section{CONCLUSION}

Propagation of new plants from PTC results in good commercial prospects in a variety of plant types including crops, fruits, vegetables, and ornamentals. More than 100 species have been reengineered using modern PTC methods in India. It is now estimated that India can produce more than 350 million cultured plants per annum.

With the applications of PTC in plant biology, several problems related to experimental biology can be resolved, which becomes a tedious task with conventional approaches. PTC is already playing a significant role in the maintenance of plant health through dimensions such as genetic engineering, breeding, and afforestation. It has been a boon for the agriculture and horticulture industries due to its numerous advantages such as pest-resistant, disease-free, and virus-free plants. It is noteworthy to mention about production of plants that are resistant to abiotic stresses and plants with biofortified properties have surely changed the direction modern-day agriculture and food production.

Commercial production of plants using PTC industries has immense scope and potential once the production units become free from all the constraints, particularly advanced research facilities, financial aspects, and marketing. Being blessed with diverse agroclimatic zones and availability of cost-effective labor, India, can flourish off the limits with the various sources from the government, as these measures can enable India to retain its self-sufficiency on agricultural production front. Furthermore, with the employment of digital technologies, one can revolutionaries the PTC industry. Development of new software to monitor the plant growth, in addition to introducing mobile apps that could help the farmers and industrialists from collection of explants to the selling the whole generated plant in market. Considering these factors, Indian tissue culture industry, though started a little later, can have its presence felt on the global scenario.

\section{AUTHOR CONTRIBUTIONS}

All authors made substantial contributions to conception and design, acquisition of data, or analysis and interpretation of data; took part in drafting the article or revising it critically for important intellectual content; agreed to submit to the current journal; gave final approval of the version to be published; and agree to be accountable for all aspects of the work. All the authors are eligible to be an author as per the international committee of medical journal editors (ICMJE) requirements/guidelines.

\section{FUNDING}

There is no funding to report.

\section{CONFLICTS OF INTEREST}

The authors report no financial or any other conflicts of interest in this work. 


\section{ETHICAL APPROVALS}

This study does not involve experiments on animals or human subjects.

\section{PUBLISHER'S NOTE}

This journal remains neutral with regard to jurisdictional claims in published institutional affiliation.

\section{REFERENCES}

1. Sen T, Samanta SK. Medicinal plants, human health and biodiversity: A broad review. In: Mukherjee J, editor. Biotechnological Applications of Biodiversity. Berlin, Heidelberg: Springer; 2014. p. 59-110.

2. Petrovska BB. Historical review of medicinal plants usage. Pharmacogn Rev 2012;11:1.

3. Sofowora A, Ogunbodede E, Onayade A. The role and place of medicinal plants in the strategies for disease prevention. Afr J Tradit Complement Altern Med 2013;5:210-29.

4. Szabados L, Kovács H, Zilberstein A, Bouchereau A. Plants in extreme environments: Importance of protective compounds in stress tolerance. In: Callow JA, editor. Advances in Botanical Research. London, UK: Academic Press; 2011. p. 105-50.

5. Tardieu F. Plant response to environmental conditions: Assessing potential production, water demand, and negative effects of water deficit. Front Physiol 2013;18:4:17.

6. Millennium Ecosystem Assessment. Ecosystems and Human Wellbeing: Synthesis. $1^{\text {st }}$ ed. Washington, DC: Island Press; 2005.

7. Dirzo R, Raven PH. Global state of biodiversity and loss. Ann Rev Environ Res 2003;28:137-67.

8. Azeez MA, Adubi AO, Durodola FA. Landraces and crop genetic improvement. In Rediscovery of Landraces as a Resource for the Future. London, United Kingdom: IntechOpen; 2018.

9. Hussain A, Qarshi IA, Nazir H, Ullah I. Plant tissue culture: Current status and opportunities. Rec Adv Plant in Vitro Cult 2012;1:1-28.

10. Oseni OM, Pande V, Nailwal TK. A review on plant tissue culture, a technique for propagation and conservation of endangered plant species. Int J Curr Microbiol Appl Sci 2018;7:3778-86.

11. Espinosa-Leal CA, Puente-Garza CA, García-Lara S. In vitro plant tissue culture: Means for production of biological active compounds. Planta 2018;248:1-8.

12. Gonçalves S, Romano A. Production of plant secondary metabolites by using biotechnological tools. Secondary metabolites, sources and applications. IntechOpen 2018;1:81-99.

13. Taşkın H, Baktemur G, Kurul M, Büyükalaca S. Use of tissue culture techniques for producing virus-free plant in garlic and their identification through real-time PCR. Sci World J 2013;2013:1-5.

14. Pathak MR, Abido MS. The role of biotechnology in the conservation of biodiversity. J Exp Biol 2014;4:352-63.

15. Krishna H, Alizadeh M, Singh D, Singh U, Chauhan N, Eftekhari M, et al. Somaclonal variations and their applications in horticultural crops improvement. Biotech 2016;6:54-72.

16. Botanical Survey of India, Annual Report 2018-19. Available from: http://www.bsi.gov.in/WriteReadData/userfiles/file/annual\%20 report\%20new/Annual\%20Report\%202018-19.pdf. [Last accessed on 2020 Apr 11].

17. Kumar VS, Navaratnam V. Neem (Azadirachta indica): Prehistory to contemporary medicinal uses to humankind. Asian Pac J Trop Biomed 2013;7:505-14.

18. Thorpe TA. History of plant tissue culture. Mol Biotechnol 2007;2:169-80.

19. Vepa SS. Impact of globalization on the food consumption of urban India. Global Food Syst Dev Ctries 2004;83:215-90.

20. García-Dorado SC, Cornselsen L, Smith R, Walls H. Economic globalization, nutrition and health: A review of quantitative evidence. Global Health 2019;15:1-15.

21. Bhatia S, Bera T, Dahiya R, Bera T, Bhatia S, Bera T. Classical and nonclassical techniques for secondary metabolite production in plant cell culture. Modern Appl Plant Biotech Pharm Sci 2015;1:231-91.

22. Govil S, Gupta SC. Commercialization of plant tissue culture in India. Plant Cell Tissue Organ Cult 1997;51:65-73.

23. Mascarenhas AF. Scope of the tissue culture industry in India. In: Plant Biotechnology in Vitro Biology in the $21^{\text {st }}$ Century. Dordrecht: Springer; 1999. p. 713-20.

24. Mavituna F. Introduction to plant biotechnology. In: Pais MS, Mavituna F, Novais JM, editors. Plant Cell Biotechnology (NATO ASI Series: Series H: Cell Biology). Berlin, Heidelberg: Springer; 1988. p. 1-14.

25. Reinert J, Bajaj YS. Applied and Fundamental Aspects of Plant Cell, Tissue, and Organ Culture. Berlin, Germany: Springer Science and Business Media; 2013.

26. Limera C, Sabbadini S, Sweet JB, Mezzetti B. New biotechnological tools for the genetic improvement of major woody fruit species. Front Plant Sci 2017;8:1418.

27. Bhojwani SS, Evans PK, Cocking EC. Protoplast technology in relation to crop plants: Progress and problems. Euphytica 1977;2:343-60.

28. Larkin PJ, Scowcroft WR. Somaclonal variation and crop improvement. In: Kosuge T, Meredith CP, Hollaender A, Wilson CM, editors. Genetic Engineering of Plants: An Agricultural Perspective (Basic Life Sciences). Boston: Springer; 1983. p. 289-314.

29. Brar D, Jain SM. Somaclonal variation: Mechanism and applications in crop improvement. In: Brar D, Jain SM, editors. Somaclonal Variation and Induced Mutations in Crop Improvement. Dordrecht: Springer; 1998. p. 15-37.

30. Staritsky G, Raghavan V. Experimental Embryogenesis in Vascular Plants. London: Academic Press; 1976.

31. Williams EG, Verry IM, Williams WM. Use of embryo culture in interspecific hybridization. In: Vasil IK, editor. Plant Improvement and Somatic Cell Genetics. London: Academic Press; 1982. p. 119-28.

32. Collins GB, Grosser JW. Culture of embryos. In: Vasil IK, editor. Cell Culture and Somatic Cell Genetics of Plants. London: Academic Press; 1984. p. 241-57.

33. Singh G, Shetty S. Impact of tissue culture on agriculture in India. Biotechnol Bioinforma Bioeng 2011;1:147-58.

34. Ragavendran C, Natarajan D. Role of plant tissue culture for improving the food security in India: A review update. In: Dhanarajan A, editor. Sustainable Agriculture towards Food Security. Singapore: Springer; 2017. p. 231-62.

35. Sidhu Y. In vitro micropropagation of medicinal plants by tissue culture. Plymouth Stud Sci 2011;4:432-49.

36. Prakash J. Micropropagation industry in India: Biology and business. Int Symp in vitro Cult Hortic Breed 2004;725:293-300.

37. Yadav SW, Ahmad AQ, Rastogi JY, Lal MA. Tissue culture strategies in sugarcane (Saccharum officinarum L.). Int J Pharm Bio Sci 2012;3:1-16.

38. Yadav N. Conservation of some endangered and economically important medicinal plants of India-a review. J Int Sci Technol 2016;2:59-62.

39. Yadav K, Singh N, Verma S. Plant tissue culture: A biotechnological tool for solving the problem of propagation of multipurpose endangered medicinal plants in India. J Agric Technol 2012;1:305-18.

40. Misra P, Shukla PK. In vitro Approaches for Mass Production of Medicinal Plants. Tamil Nadu: MacMillan E-Publishing Co.; 2010. p. 94-102.

41. Debnath M, Malik CP, Bisen PS. Micropropagation: A tool for the production of high quality plant-based medicines. Curr Pharm Biotechnol 2006;1:33-49.

42. Krishnan PN, Decruse SW, Radha RK. Conservation of medicinal 
plants of Western Ghats, India and its sustainable utilization through in vitro technology. In Vitro Cell Dev Biol Plant 2011;1:110-22.

43. Nadgauda RS, Kendurkar SV, Mascarenhas AF. Commercialisation of tissue culture for forest tree species in India. In: Altman A, Ziv M, Izhar S, editors. Plant Biotechnology and in Vitro Biology in the $21^{\text {st }}$ Century. Dordrecht: Springer; 1999. p. 721-4.

44. Mascarenhas AF, Khuspe SS, Nadgauda RS, Gupta PK, Muralidharan EM, Khan BM. Biotechnological application of plant tissue culture to forestry in India. In: Dhawan V, editor. Applications of Biotechnology in Forestry and Horticulture. Boston: Springer; 1989. p. 73-86.

45. Fay MF. Conservation of rare and endangered plants using in vitro methods. In Vitro Cell Dev Biol Plant 1992;1:1-4.

46. Tandon P, Kumaria S, Nongrum L. Conservation and management of plant genetic resources of Northeast India. Indian J Tradit Know 2009;1:29-34.

47. Tandon P, Kumaria S, Das MC. Plant resources of India: Potentials for future development. Proc Nat Acad Sci Biol Sci 2012;82:283-9.

48. NCS-STP, Recognition of Tissue Culture Production Facilities. Available from: https://www.dbtncstcp.nic.in/-Recognition-of-TissueCulture-Production-Facilities. [Last accessed on 2020 Apr 12].

49. TERI, Micro propagation Technology Park. Facilities. Available from: https://www.teriin.org/project/micropropagation-technologypark. [Last accessed on $2020 \mathrm{Apr} 12$ ].

50. NCS-STP, Plant Tissue Culture-Techno-commercial Feasibility. Available from: https://www.dbtncstcp.nic.in/Portals/0/Images/ Plant-Tissue-Culture.-Techno-Commercial-Feasibility.pdf. [Last accessed on 2020 Apr 12].

51. Kettenburg AJ, Hanspach J, Abson DJ, Fischer J. From disagreements to dialogue: Unpacking the golden rice debate. Sustain Sci 2018;5:1469-82.

52. Ramu R, Shirahatti PS, Shrisha NB, Varsha RSV, Nagendra MN. Impact of active compounds isolated from banana (Musa sp. var. Nanjangud rasabale) flower and pseudostem towards cytoprotective and DNA protection activities. Int J Pharm Sci 2017;9 (10):21-23.

53. Ravi K, Divyashree P. Psidium guajava: A review on its potential as an adjunct in treating periodontal disease. Pharmacogn Rev 2014;16:96-100.

54. Telang M, Dhulap S, Mandhare A, Hirwani R. Therapeutic and cosmetic applications of mangiferin: A patent review. Exp Opin Ther Pat 2013;12:1561-80.

55. Karimi A, Majlesi M, Rafieian-Kopaei M. Herbal versus synthetic drugs; beliefs and facts. J Nephropharmacol 2015;1:27-30.

56. Krikorian AD. Plant tissue culture: Perceptions and realities. Proc Plant Sci 1988;6:425.

57. Jacob SR, Tyagi V, Agrawal A, Chakrabarty SK, Tyagi RK. Indian plant germplasm on the global platter: An analysis. PLoS One 2015;5:e126634.

58. Patil SM, Sujay S, Tejaswini M, Sushma PP, Prithvi S, Ramu R. Bioactive peptides: Its production and potential role on health. Int J Innov Sci Eng Tech 2020;1:167-82.

\section{How to cite this article:}

Patil SM, Kumari VBC, Sumana K, Sujay, S, Tejaswini M, Shirahatti PS,

Ramu R. Sustainable development of plant tissue culture industry: The Indian scenario. J App Biol Biotech. 2021;9(2):18-27.

DOI: $10.7324 / J A B B .2021 .9202$ 